\title{
Adenylate Energy Charge during Batch Culture of Beneckea natriegens
}

\author{
By D. F. NIVEN,* PAULINE A. COLlins and C. J. KNOWLES \\ Biological Laboratories, University of Kent, Canterbury $\mathrm{CT}_{2}{ }_{7} \mathrm{NJ}$
}

(Received 25 May 1976; revised 19 July 1976)

\begin{abstract}
SU M M A R Y
The value of the adenylate energy charge, i.e. ([ATP] $\left.+\frac{1}{2}[\mathrm{ADP}]\right) /([\mathrm{ATP}]+[\mathrm{ADP}]$ + [AMP]), during batch culture of Beneckea natriegens remained relatively constant during the exponential and early stationary phases of the growth cycle. During exponential growth the intracellular ATP content remained constant, the amount of ATP in the culture increasing proportionally with growth; these conditions were unaltered during growth in the presence of added cyclic AMP. On cessation of growth, significant variation in bacterial ATP content was observed depending on whether growth of the cultures terminated due to exhaustion of carbon or nitrogen from the medium, and on the presence or absence of added cyclic AMP.
\end{abstract}

\section{INTRODUCTION}

The adenylate energy charge (Atkinson \& Walton, 1967; Atkinson, 1968) probably plays a significant role in metabolic regulation although some doubts have been expressed (Purich \& Fromm, 1972, 1973). Extensive studies of various enzyme systems from widely differing sources (Klungsøyr et al., I968; Shen et al., I968; Shen \& Atkinson, 1970; Liao \& Atkinson, 1971; Thompson \& Atkinson, 1971; Miller \& Atkinson, 1972; Chulavatnatol \& Atkinson, 1973a,b) and of the adenylate energy charge during growth and/or starvation of several prokaryotic and eukaryotic micro-organisms (Chapman, Fall \& Atkinson, 197I; Miović \& Gibson, 1971, 1973; Bächi \& Ettlinger, I973; Montague \& Dawes, 1974; Slayman, 1973; Dietzler, Lais \& Leckie, 1974a; Dietzler et al., 1974b; Hutchison \& Hanson, 1974; Ball \& Atkinson, 1975; Eigener, 1975; Eigener \& Bock, 1975; Gadkari \& Stolp, 1975; Swedes, Sedo \& Atkinson, 1975) have established the role of energy charge as a regulatory parameter. The finding that the energy charge can remain constant even when the total adenylate pool or ATP levels decrease drastically (Dietzler et al., 1974b; Swedes et al., 1975 appears to substantiate this conclusion. Recent work (Chapman \& Atkinson, 1973; Schramm \& Leung, 1973; Schramm \& Lazorik, 1975) has afforded an explanation of such energy charge stabilization, energy charge itself being involved in the regulation of AMP breakdown.

Studies on the effect of growth rate on the ATP content of various bacteria (expressed as ATP content per mg dry wt or mg protein rather than as ATP content per cell, as cell size can vary with growth rate) have so far led to conflicting results: ATP pools have been claimed to be either independent of growth rate (Franzen \& Binkley, 196I; Smith \& Maaløe 1964; Harrison \& Maitra, I969; Hobson \& Summers, 1972; Miović \& Gibson, 1973), or to increase with growth rate (Neidhardt \& Fraenkel, 1961; Bagnara \& Finch, 1973). Since the rate of turnover of ATP depends on the pool size, rapid growth of bacteria could be associated either with a large ATP pool or with an increase in the rate of turnover.

* Present address: Department of Microbiology, Macdonald College, Quebec HOA ICO, Canada. 
The purpose of this investigation was to monitor various parameters, including ATP levels and adenylate energy charge, in the marine bacterium Beneckea natriegens during batch culture under carefully controlled growth conditions. This organism was selected because it is capable of extremely rapid growth; in glucose/minimal salts medium it has a mean generation time of 24 to 26 min (see below) and Eagon (I962) has claimed that it can double in $9.8 \mathrm{~min}$ in rich media. Whether ATP turnover or ATP pool size increases with growth rate, the regulatory processes controlling the adenine nucleotide pools must be extremely efficient.

As the total ATP pools turn over many times per second, even in bacteria growing at relatively modest rates (Harrison \& Maitra, I969; Holms, Hamilton \& Robertson, I972; Miović \& Gibson, 1973), rapid sampling and quenching are essential for reliable estimates of adenine nucleotide composition of growing bacteria, and hence determination of their energy charge values. To date, insufficient attention has been paid to the problems associated with the rapid monitoring of adenine nucleotide levels although Harrison \& Maitra (I969) have described a simple method of rapid sampling and quenching of bacterial samples from continuous cultures. Consequently, in the present study, particular attention has been given to these problems. A simple spring-loaded syringe unit was devised which permits extremely rapid sampling from the growing culture, and the quenching reagent (perchloric acid) rapidly and irreversibly terminates metabolic activity and destroys any enzymes which might affect the adenine nucleotide composition (see Lundin \& Thore, 1975).

Considerable attention is now being given to regulatory control exerted by cyclic AMP in prokaryotes (Rickenberg, I974). Cyclic AMP levels are involved in the control of tricarboxylic acid cycle enzyme synthesis (Takahashi, 1975) and various membrane-associated phenomena (see Patrick \& Dobrogosz, I973) including cytochrome synthesis (Broman, Dobrogosz \& White, 1974), membrane transport (Ezzell \& Drobrogosz, 1975) and possibly oxidative phosphorylation (Hempfling, 1970; Hempfling \& Beeman, 1971; Hempfling \& Mainzer, 1975). In addition, adenylate cyclase (EC. 4.6.I.I) is an ATP-utilizing enzyme, which suggests that either it or cyclic-AMP phosphodiesterase (EC. 3. I.4 I7) may perhaps be regulated by energy charge such that these two major overall regulatory parameters influencing metabolic activity could be interrelated. Therefore we have also investigated the effect of cyclic AMP on adenine nucleotide content and energy charge during the growth cycle of $B$. natriegens.

\section{METHODS}

Organism and medium. Beneckea natriegens strain I I I (Baumann, Baumann \& Mandel, 1971) was grown in a defined medium which contained $50 \mathrm{~mm}-\mathrm{Tris} / \mathrm{HCl}, 400 \mathrm{mM}-\mathrm{NaCl}$, Io mM-KCl, 3.3 mM- $\mathrm{K}_{2} \mathrm{HPO}_{4}$, O.I mM-Na $\mathrm{EDTA}_{2}$, O. I mM-FeSO, $\mathrm{I} \cdot 0 \mathrm{~mm}-\mathrm{MgSO}_{4}$, I.0 mM$\mathrm{CaCl}_{2}, 25 \mathrm{mM}-\mathrm{NH}_{4} \mathrm{Cl}$ (or $2.5 \mathrm{mM}-\mathrm{NH}_{4} \mathrm{Cl}$ for nitrogen-limited growth), and $\mathrm{HCl}$ to $\mathrm{pH} 7.5$. Glucose ( $5 \mathrm{mM}$ ) or sodium succinate (Io $\mathrm{mM}$ ) were added as carbon sources. Where appropriate, cyclic AMP was neutralized with $\mathrm{KOH}$, sterilized by filtration, and added to a final concentration of $2 \mathrm{mM}$.

In this study, the terms 'nitrogen-limited' and 'carbon-limited' are used to indicate the substrates, depletion of which causes termination of growth.

Growth and preparation of inocula. Bacteria for inocula were grown in $100 \mathrm{ml}$ carbonlimited medium (without added cyclic AMP) in $250 \mathrm{ml}$ conical flasks for $\mathrm{I} 6 \mathrm{~h}$ at $35^{\circ} \mathrm{C}$ in a rotary shaker ( $\left.200 \mathrm{rev} . \mathrm{min}^{-1}\right) ; 20 \mathrm{ml}$ of this culture was then used to inoculate I 1 carbonlimited medium. For nitrogen-limited cultures, bacteria, grown as before in carbon-limited medium, were harvested aseptically $(23000 \mathrm{~g}$; Io $\mathrm{min}$ ) and resuspended in an equal volume 
of sterile growth medium lacking $\mathrm{NH}_{4} \mathrm{Cl}$, carbon source and cyclic AMP; $20 \mathrm{ml}$ was then used to inoculate I 1 medium.

Growth of experimental cultures. Bacteria were grown in a 1 Quickfit fermentation vessel which had been modified by fitting a sampling/injection port, taking a no. 33 Suba-Seal stopper (Astell Laboratory Service Co., Catford, London), to the vertical face of the vessel at its base. This vessel was fitted with a Quickfit lid which had five ports accommodating, respectively, air input tube plus thermometer, air exhaust (via a condenser), heating finger, galvanic-cell oxygen probe (L.H. Engineering Co., Stoke Poges, Buckinghamshire), and pH electrode coupled to a remote calomel reference electrode (L.H. Engineering Co.). The culture, which was maintained at $35^{\circ} \mathrm{C}$, was aerated by passing sterile air through it at $1.251 \mathrm{~min}^{-1}$ and stirring continuously with a Teflon-coated magnetic stirring bar. The oxygen electrode was connected in series with a $\mathrm{I} \mathrm{k} \Omega$ variable potentiometer so that the dissolved oxygen tension could be conveniently measured on a chart recorder $(\mathrm{W}+\mathrm{W}$ Series I I00, W + W Electronic Inc., Basel, Switzerland). The $\mathrm{pH}$ and reference electrodes were connected to a Pye Unicam model $292 \mathrm{pH}$ meter which was connected in series with a $\mathrm{I} \mathrm{k} \Omega$ variable potentiometer to a chart recorder ( $\mathrm{W}+\mathrm{W}$ Series I IOO) so that full-scale deflexion could be adjusted to read $5 \mathrm{pH}$ units.

Samples of medium and culture were removed with sterile syringes and needles via the Suba-Seal stopper (sterilized by swabbing with $95 \%$ ethanol) both before and after inoculation in order to test the sterility of the medium and the purity of the culture respectively.

Bacterial growth was monitored turbidimetrically at $680 \mathrm{~nm}$ by removing samples in the same way.

Estimation of bacterial dry weight. Duplicate $8 \mathrm{ml}$ samples of a succinate-limited culture grown for $16 \mathrm{~h}$ were used to inoculate $2 \times 400 \mathrm{ml}$ medium containing Io mM-sodium succinate in 21 baffled flasks. Incubation was at $35^{\circ} \mathrm{C}$ in a rotary shaker (200 rev. $\left.\mathrm{min}^{-1}\right)$ and growth was allowed to proceed to the mid-exponential phase $\left(E_{680}\right.$ about 0.5$)$. The bacteria were harvested by centrifuging $(23000 \mathrm{~g}$; I $\mathrm{min})$ and washed in a pre-weighed polypropylene centrifuge tube with $40 \mathrm{ml} 50 \mathrm{~mm}$ Tris/ $\mathrm{HCl}$ containing $400 \mathrm{~mm}-\mathrm{NaCl}, 10 \mathrm{~mm}-\mathrm{KCl}, \mathrm{I} \cdot 0 \mathrm{~mm}-$ $\mathrm{MgSO}_{4}, \mathrm{pH} 7 \cdot 5$. The washing buffer was discarded, the centrifuge tube was carefully wiped dry and the wet weight of the bacteria was determined. The bacterial pellet was resuspended in $6 \mathrm{ml} 50 \mathrm{~mm}$-Tris/ $\mathrm{HCl}$ containing $400 \mathrm{~mm}-\mathrm{NaCl}, \mathrm{I}$ ( $\mathrm{mm}-\mathrm{KCl}, \mathrm{I} \cdot 0 \mathrm{~mm}-\mathrm{MgSO}_{4}, \mathrm{pH} 7 \cdot 5$, and $\mathrm{I} \mathrm{ml}$ portions of this were removed to pre-weighed aluminium planchettes, as were similar portions of the suspension buffer. The planchettes and contents were dried to constant weight at about $100{ }^{\circ} \mathrm{C}$. Because of the high salt concentrations required for osmotic stabilization of $B$. natriegens, estimates of bacterial dry weight were limited by the weight of the salts involved, the density of the bacterial suspension used and the volume occupied by the bacteria per se. The density of wet pelleted bacteria was therefore assumed to be approximately $\mathrm{I} \cdot \mathrm{I} 7 \mathrm{~g} \mathrm{ml}^{-1}$ and a small correction factor was employed in the calculations. An $E_{680}$ of I $\cdot 0$ for the growing culture was equivalent to a cell density of $0.4 \mathrm{mg}$ dry bacterial wt $\mathrm{ml}^{-1}$.

Sampling and preparation of extracts. To collect the samples used in the determination of ATP, ADP and AMP in the culture, cold $25 \% \mathrm{HClO}_{4}(200 \mu 1)$ was loaded into a I $\mathrm{ml}$ glass syringe held in a specially designed double-stop spring-loaded syringe unit. A sterile needle was then attached to the syringe and a sample of the culture (about $0.8 \mathrm{ml}$ ) was withdrawn, via the Suba-Seal stopper, into the $\mathrm{HClO}_{4}$ under the action of the spring-loading mechanism. By this technique, extremely rapid sampling times $(<50 \mathrm{~ms})$ could be achieved, thereby minimizing ATP losses due to its high rate of turnover (see Holms et al., 1972). The syringe needle was discarded and the sample was quickly ejected into a small test tube on ice. 
Samples were left on ice for $15 \mathrm{~min}$, their volumes were recorded, and they were then neutralized carefully (to $\mathrm{pH} 7 \cdot 3$ ) with saturated $\mathrm{KOH} / 2 \mathrm{M}$-Tris base/water (30:60: 10 , by vol.). After centrifuging ( $3000 \mathrm{~g}$; $15 \mathrm{~min} ; 4^{\circ} \mathrm{C}$ ), the supernatant fractions were retained and stored at $-22{ }^{\circ} \mathrm{C}$ for a maximum of $48 \mathrm{~h}$.

Samples $(\mathrm{I} \cdot \mathrm{O} \mathrm{ml})$ collected for the determination of extracellular adenine nucleotides were removed from the culture via the Suba-Seal stopper using sterile syringes and needles, filtered immediately (Oxoid MF50 filters; $0.45 \mu \mathrm{m}$ pore size), and $0.8 \mathrm{ml}$ of the filtrate was rapidly mixed with $0.2 \mathrm{ml} 25 \% \mathrm{HClO}_{4}$. The samples were kept on ice, neutralized, centrifuged and stored as described above.

Preparation of samples for the luciferase assay. For ATP determinations, extract $(200 \mu \mathrm{l})$ was added to $50 \mu 1 \mathrm{I}_{5} \mathrm{~mm}_{-\mathrm{MgSO}_{4}}$ in $100 \mathrm{~mm}$-Tris/acetic acid, $\mathrm{pH} \mathrm{7 \cdot 3}$. For ATP plus ADP determinations, extract $(200 \mu \mathrm{l})$ was added to $50 \mu \mathrm{l} \mathrm{I} 5 \mathrm{~mm}_{-} \mathrm{MgSO}_{4}$ in $\mathrm{I} 00 \mathrm{mM}^{-T r i s} /$ acetic acid, $\mathrm{pH} 7 \cdot 3$, containing $0.5 \mathrm{~mm}$-phosphoenolpyruvate and $2 \mu \mathrm{g}$ pyruvate kinase EC. 2.7 . I .40). For total adenylate determinations, extract ( $200 \mu \mathrm{l})$ was added to $50 \mu 1$ I $5 \mathrm{mM}$ $\mathrm{MgSO}_{4}$ in $100 \mathrm{~mm}$-Tris/acetic acid, $\mathrm{pH} 7.3$, containing $0.5 \mathrm{~mm}$-phosphoenolpyruvate, $2 \mu \mathrm{g}$ pyruvate kinase and $5 \mu \mathrm{g}$ adenylate kinase (EC. $2 \cdot 7 \cdot 4 \cdot 3$ ). These mixtures were incubated at $30{ }^{\circ} \mathrm{C}$ for $15 \mathrm{~min}$ and held on ice until assayed ( $<\mathrm{I} 5 \mathrm{~min}$ ).

Preparation of firefly lantern extract. Commercial firefly lantern extract was reconstituted with cold water and the vial and contents were gently mixed on a Taab rotator ( $2 \mathrm{rev} . \mathrm{min}^{\mathbf{1}}$; Taab Laboratories, Reading, Berkshire) at $4{ }^{\circ} \mathrm{C}$ for $24 \mathrm{~h}$ in the dark. The extract was centrifuged $\left(20000 \mathrm{~g} ; 30 \mathrm{~min} ; 4{ }^{\circ} \mathrm{C}\right)$ and the supernatant fraction was divided into $2 \mathrm{ml}$ portions which were stored at $-22{ }^{\circ} \mathrm{C}$ until required. Immediately before use, portions were thawed, diluted with an equal volume of $50 \mathrm{mM}-\mathrm{Na}_{2} \mathrm{HAsO}_{4} / 20 \mathrm{mM}-\mathrm{MgSO}_{4}$ brought to $\mathrm{pH} 7 \cdot 4$ with $\mathrm{H}_{2} \mathrm{SO}_{4}$ and centrifuged ( $3000 \mathrm{~g}$; $\mathrm{I} 5 \mathrm{~min} ; 4{ }^{\circ} \mathrm{C}$ ) to remove any precipitate. The supernatant fraction was retained and stored in the dark at $4{ }^{\circ} \mathrm{C}$ until required.

Luciferase assays. Incubated samples $(25 \mu 1)$ were added to $6 \times 50 \mathrm{~mm}$ glass tubes (Sharples, Upper Norwood, London) followed by $75 \mu \mathrm{l}$ cold $3 \mathrm{mM}^{-\mathrm{MgSO}_{4}}$ in $20 \mathrm{mM}$-Tris/acetic acid, $\mathrm{pH}_{7} \cdot 4$, and $200 \mu$ l cold 3 mM- $\mathrm{MgSO}_{4}$, in Ioo mM-glycylglycine brought to $\mathrm{pH} 7 \cdot 4$ with $\mathrm{KOH}$. Such samples were equilibrated to room temperature (10 min) in a dark room lit by dim yellow safelights; the diluted firefly lantern extract was similarly equilibrated. A sample tube was placed in the reaction chamber of an Aminco Chem-Glow Photometer (American Instrument Co., Silver Spring, Maryland, U.S.A.) which was coupled to a chart recorder, and the chemiluminescence was measured after adding $100 \mu 1$ diluted firefly lantern extract from a $5 \mathrm{ml}$ gas-tight syringe (model 1005 , Hamilton Co., Whittier, California, U.S.A.) held in a Hamilton repeating dispenser (model PB600-I0).

The method of internal standardization was used in all ATP determinations and the instrument was also routinely calibrated with stock ATP solutions of known concentration. ADP and AMP were determined by difference.

Glucose assays. To $25 \mu \mathrm{l}$ neutralized extract in $225 \mu \mathrm{l}$ water was added $\mathrm{I} \cdot 25 \mathrm{ml}$ of a solution containing $100 \mathrm{ml} 0.5 \mathrm{M}-\mathrm{Na}_{2} \mathrm{HPO}_{4} / \mathrm{NaH}_{2} \mathrm{PO}_{4}$ buffer, $\mathrm{pH} 7.0$, $10 \mathrm{mg}$ glucose oxidase (EC. I I I.3 .4), $10 \mathrm{mg}$ peroxidase (EC. I . I I. I .7), and $0.5 \mathrm{ml} \mathrm{I} \%$ (w/v) 0 -dianisidine in methanol. Samples were incubated at $30{ }^{\circ} \mathrm{C}$ for $45 \mathrm{~min}$ and their absorbance at $437 \mathrm{~nm}$ was measured. A calibration plot was constructed using standard glucose solutions.

Succinate assays. Neutralized extract ( $\mathrm{I} 5 \mu \mathrm{l})$ was added to $\mathrm{I} \cdot 485 \mathrm{ml}$ of a solution containing 0.225 mM-NADH, $0.5 \mathrm{~mm}-\mathrm{CoA}, 0.05 \mathrm{mM}-\mathrm{GTP}, \mathrm{I} \cdot 0 \mathrm{~mm}$-phosphoenolpyruvate, io $\mu \mathrm{g}$ pyruvate kinase, Io $\mu$ g lactate dehydrogenase (EC. I.I.I.27), $30 \mu \mathrm{g}$ succinate thiokinase (EC. 6.2.I.4), $\mathrm{I} \cdot 0 \mathrm{mM}^{-\mathrm{K}_{2}} \mathrm{SO}_{4}$ and $4.5 \mathrm{mM}^{-\mathrm{MgSO}_{4}}$ in $75 \mathrm{~mm}$-triethanolamine hydrochloride, $\mathrm{pH}_{7} \cdot 4$. Control mixtures contained either ${ }_{5} \mu \mathrm{l}$ ro mM-sodium succinate in 75 mM-triethanol- 
amine hydrochloride, $\mathrm{pH} 7 \cdot 4$, or I $5 \mu 175 \mathrm{~mm}$-triethanolamine hydrochloride, $\mathrm{pH} 7 \cdot 4$, instead of neutralized extract; the latter control allowed for the small reaction that took place due to GDP contamination of the GTP. Samples were incubated for $\mathrm{I} h$ at $30^{\circ} \mathrm{C}$ and their absorbance at $340 \mathrm{~nm}$ was measured.

Chemicals. Cyclic AMP, ATP (Sigma grade, disodium salt), ADP (grade I, sodium salt), AMP (type III), NADH (grade III), phosphoenolpyruvate (tricyclohexylamine salt), glycylglycine (free base), Tris (Trizma base), firefly lantern extract (FLE-250), adenylate kinase (myokinase, grade III), glucose oxidase (type II), peroxidase (type I), lactate dehydrogenase (type III) and succinate thiokinase were obtained from Sigma. Pyruvate kinase $\left(\left(\mathrm{NH}_{4}\right)_{2} \mathrm{SO}_{4}\right.$ suspension), CoA (grade I, free acid) and GTP (trisodium salt) were obtained from Boehringer. Whenever possible, all other reagents were of analytical grade; glass-distilled water was used throughout.

\section{RESULTS}

\section{Growth on succinate}

Growth of Beneckea natriegens on succinate (Fig. I $a$ ) was accompanied by a high respiratory rate, as evidenced by the decreasing dissolved oxygen tension (Fig. I $b$ ), and an increase in the culture $\mathrm{pH}$ (Fig. I $b$ ). The final level of oxygen tension attained was not sufficient to cause oxygen limitation of growth. The concentration of ATP in the culture increased proportionally with growth such that the intracellular ATP content remained constant at approximately $7 \mathrm{nmol}(\mathrm{mg} \text { dry bacterial } \mathrm{wt})^{-1}$ (Fig. I $c$ ). At the onset of the stationary phase, when respiratory activity decreased dramatically, fluctuations in the bacterial ATP content occurred followed by a slight decrease towards the end of the incubation period. However, the adenylate energy charge remained relatively constant throughout the experiment. In this and the other experiments described, unless otherwise stated, the levels of extracellular adenine nucleotides were negligible and the intracellular ADP and AMP concentrations were very small with respect to those of ATP (i.e. conditions of high energy charge). Therefore, large changes in the cellular ATP content of the culture reflected similar fluctuations in the level of total adenylates.

When growth on succinate was limited by the lack of a nitrogen supply (Fig. 2a), approximately $50 \%$ of the succinate still remained on cessation of exponential growth. Respiratory activity, which was again high during the growth period (Fig. 2b), decreased when the bacteria entered the stationary phase of growth and declined slowly as the succinate was utilized. The exhaustion of succinate (Fig. $2 a$ ) was accompanied by a further decrease in respiratory activity associated with the oxidation of endogenous reserves (Fig. $2 b$ ). The adenylate energy charge remained relatively stable during the experiment (Fig. 2a). Figure $2 c$ shows the ATP content of the bacteria and of the culture, the former remaining constant during exponential growth at approximately $5 \mathrm{nmol}(\mathrm{mg} \text { dry bacterial } \mathrm{wt})^{-1}$. Whereas the onset of the stationary phase in the succinate-limited culture was accompanied by only a small increase in bacterial ATP content (Fig. I $c$ ), the ATP content of the nitrogen-limited succinate-grown bacteria continued to increase rapidly until the succinate was exhausted (Fig. $2 c$ ). Thereafter the ATP level transiently decreased but recovered before the end of the incubation period. The culture $\mathrm{pH}$ increased during the experiment (Fig. $2 b$ ).

\section{Growth on glucose}

Beneckea natriegens grew extremely well on the glucose/minimal salts medium (Fig. $3 a$ ), the mean generation time being approximately $25 \mathrm{~min}$. Both respiratory rate and acid production (see Eagon \& Cho, 1965) were high during growth (Fig. $3 b$ ) and these activities 

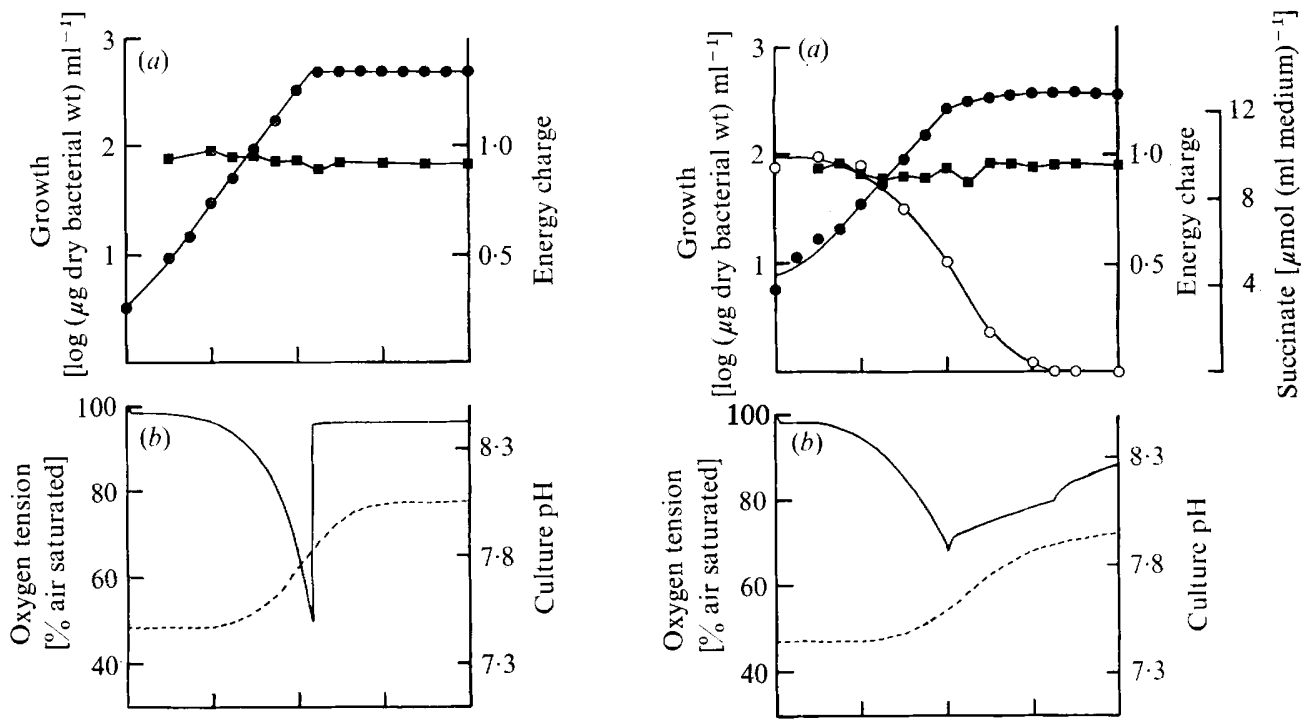

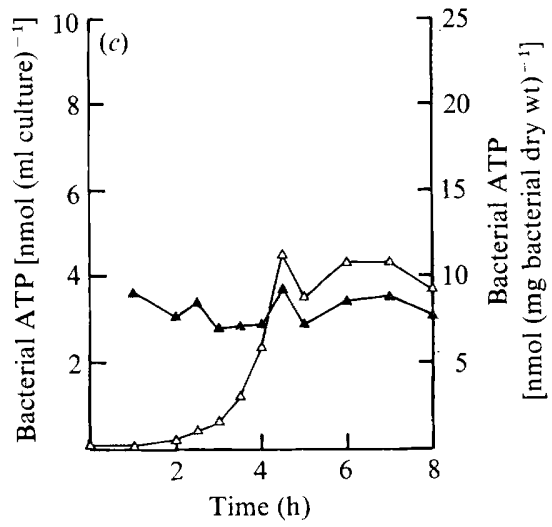

Fig. I

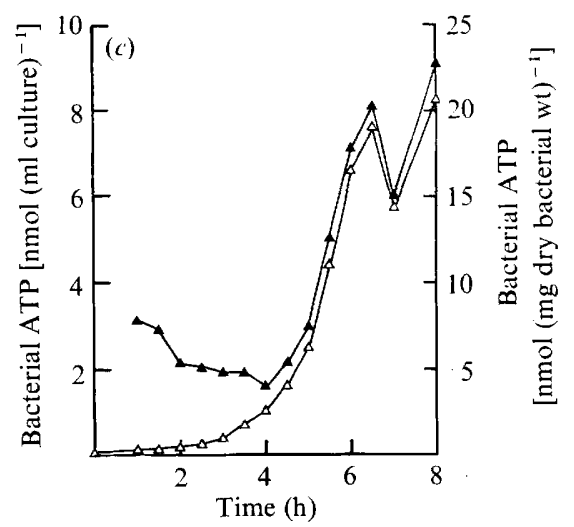

Fig. 2

Fig. I. Energy charge and ATP levels during batch culture of B. natriegens on succinate. (a) growth; $\boldsymbol{\square}$, energy charge. $(b) \_$, oxygen tension; - - - - , culture $\mathrm{pH}$. (c) $\triangle$, bacterial ATP content per ml culture; $\boldsymbol{\Lambda}$, bacterial ATP content per mg dry bacterial wt.

Fig. 2. Energy charge and ATP levels during nitrogen-limited batch culture of $B$. natriegens on succinate. Symbols as in Fig. 1 ; except $O$, succinate concentration.

ceased immediately the glucose was exhausted and growth stopped. The acids which had been produced during growth were then utilized, as evidenced by the increasing culture $\mathrm{pH}$ and the second phase of respiratory activity; these acids did not sustain further growth. The abrupt termination of the second respiratory phase coincided with depletion of the acidic substrates as seen by the cessation of the change in culture $\mathrm{pH}$. Adenylate energy charge again remained relatively constant during the investigation. The cellular ATP level of the culture (Fig. $3 \mathrm{c}$ ) increased with biomass and the bacterial ATP content was therefore constant during growth at about $6 \mathrm{nmol}(\mathrm{mg} \text { dry bacterial } \mathrm{wt})^{-1}$. Once exponential growth had ceased, the bacterial ATP content increased to approximately $9 \mathrm{nmol}$ ( $\mathrm{mg}$ dry bacterial $w t)^{-1}$ and remained at this value until the end of the second respiratory phase when it decreased to a steady level. 

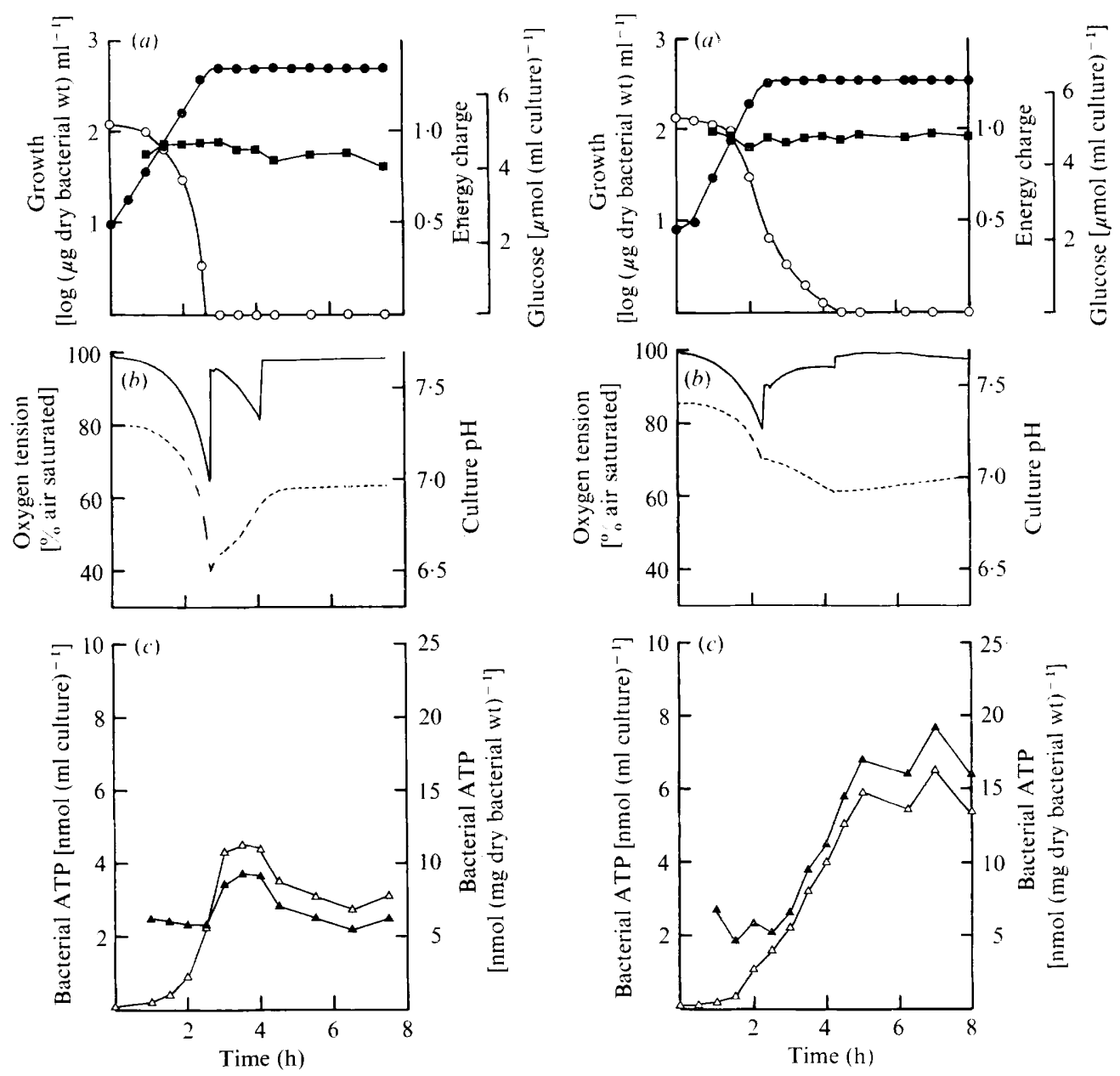

Fig. 3

Fig. 4

Fig. 3. Energy charge and ATP levels during batch culture of B. natriegens on glucose. Symbols as in Fig. I; except $O$, glucose concentration.

Fig. 4. Energy charge and ATP levels during nitrogen-limited batch culture of B. natriegens on glucose. Symbols as in Fig. I; except $\bigcirc$, glucose concentration.

In a similar experiment in which the initial glucose concentration was near $14 \mathrm{~mm}$, growth was found to be $\mathrm{pH}$-limited, the $\mathrm{pH}$ of the culture falling to $\mathrm{pH} 4 \cdot 2$ while the culture glucose concentration decreased to, and remained at $7 \mathrm{mM}$. Until the culture $\mathrm{pH}$ dropped below $\mathrm{pH} 6 \cdot 5$, this experiment gave identical results to the previous one. When the $\mathrm{pH}$ reached $\mathrm{pH} 5.8$, the dissolved oxygen tension began to increase and had returned to $95 \%$ when the culture $\mathrm{pH}$ was $\mathrm{pH} 4.7$ ( $3 \mathrm{~h}$ incubation). Thereafter the adenylate energy charge decreased rapidly to about 0.5 . The intracellular ATP content was constant at $4.5 \mathrm{nmol}$ (mg dry bacterial wt) ${ }^{-1}$ up to and including a sample taken at $2.5 \mathrm{~h}$ (just before the $\mathrm{pH}$ dropped to $\mathrm{pH} 4 \cdot 7$ ) but increased to $7.7 \mathrm{nmol}$ (mg dry bacterial wt) ${ }^{-1}$ at $3 \mathrm{~h}$ when growth had stopped; the ATP level then rapidly decreased to $0.4 \mathrm{nmol}$ (mg dry bacterial wt $)^{-1}$ at $3.5 \mathrm{~h}$, and remained at this level until the end of the incubation period $(8 \mathrm{~h})$. 
Bacterial lysis also occurred from $3.5 \mathrm{~h}$ onwards, bacterial mass, as measured by turbidity, decreasing to $43 \%$ of the maximum attained, by $8 \mathrm{~h}$; lysis was also confirmed by the extensive release of adenine nucleotides into the medium.

When growth on glucose was limited by the lack of a nitrogen supply (Fig. $4 a$ ), 50 to $55 \%$ of the glucose supplied was utilized during exponential growth. The results obtained during this period were very similar to those observed over the same time interval in glucose-limited culture (Fig. 3). Respiratory activity and acid production decreased as the bacteria entered the stationary phase (Fig. $4 b$ ) and oxygen consumption declined slowly as the glucose was metabolized. The exhaustion of glucose (Fig. $4 a$ ) was accompanied by a further decrease in respiratory activity; this new respiratory rate was associated with the oxidation of the acids produced since the culture $\mathrm{pH}$ slowly increased (Fig. $4 b$ ). The adenylate energy charge again remained relatively stable during the experiment (Fig. $4 a$ ). Figure $4 c$ shows the ATP content of the bacteria and of the culture, the former remaining constant during exponential growth at approximately $5 \mathrm{nmol}(\mathrm{mg} \text { dry bacterial } \mathrm{wt})^{-1}$. Whereas the bacterial ATP content of the glucose-limited culture (Fig. $3 \mathrm{c}$ ) increased on cessation of growth and remained steady during the second respiratory phase, that of the nitrogen-limited glucose-grown culture increased when growth stopped and continued to increase throughout the second respiratory phase (Fig. $4 \mathrm{c}$ ) not unlike the situation with the nitrogen-limited succinate-grown culture (Fig. 2c). However, after the glucose was exhausted, the bacterial ATP content continued to increase for a period before attaining a steady level (Fig. 4).

\section{Effect of cyclic AMP in growth medium}

When a glucose-limited culture was grown in the presence of cyclic AMP, the results (Fig. 5) were similar to those obtained with the glucose-limited culture (Fig. 3). However, in the presence of cyclic AMP much less acid was produced during growth as evidenced by the changes in $\mathrm{pH}$ and also by the time taken to metabolize the acidic material oxidatively (Fig. $5 b$ ). The bacterial ATP contents also differed: whilst the constant levels associated with growth were approximately the same, those achieved during the second respiratory phase were significantly higher in the culture grown in the presence of cyclic AMP (Fig. $5 c$ ); the steady level of bacterial ATP which was maintained after the second respiratory phase was also higher when cyclic AMP was present. The adenylate energy charge, however, was similar to that in the absence of cyclic AMP and remained relatively constant during the incubation (Fig. $5 a$ ).

When B. natriegens was grown on glucose under nitrogen-limited conditions in the presence of cyclic AMP, the results obtained (not presented) were similar to those obtained for nitrogen-limited growth in the absence of cyclic AMP (Fig. 4) except that the bacterial ATP contents during and after the second respiratory phase were slightly higher in the presence of cyclic AMP, and a small diauxic effect was observed (see below). The results obtained during the initial exponential phase of growth were also, as expected, similar to those observed over the same time interval with the glucose-limited culture in the presence of cyclic AMP (Fig. 5).

The reasons for the second growth phase remain obscure; further investigations have confirmed the diauxie in nitrogen-limited cultures grown in the presence of cyclic AMP and the absence of such an effect in carbon-limited cultures (plus cyclic AMP). Spectral and chromatographic analyses of the commercial cyclic AMP preparation revealed no nitrogenous or other impurities. Cultures grew well on $5^{\prime}$-AMP as sole carbon and/or nitrogen source. By using a medium of high buffering capacity $(250 \mathrm{~mm}-\mathrm{Tris} / \mathrm{HCl})$ and $25 \mathrm{~mm}-$ 

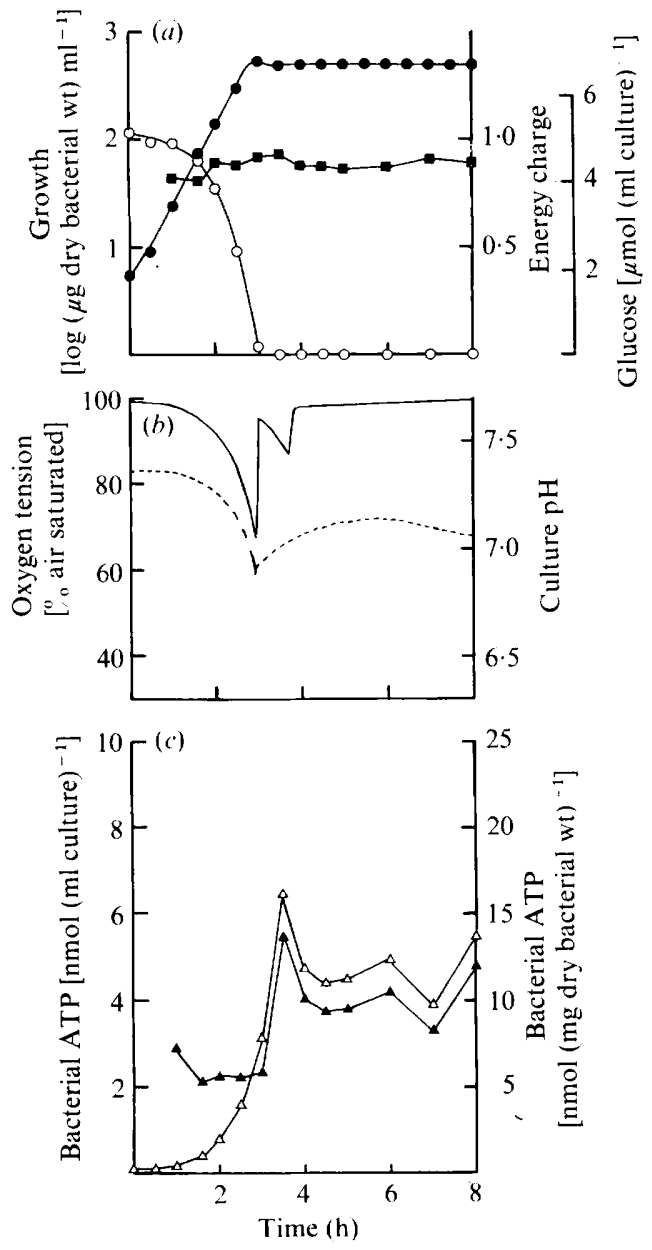

Fig. 5. Energy charge and ATP levels during batch culture of B. natriegens on glucose in the presence of cyclic AMP. Symbols as in Fig. I ; except $\bigcirc$, glucose concentration.

glucose, it was shown that in nitrogen-limited cultures in the presence of cyclic AMP, the second growth phase was also limited by the nitrogen supply. Chromatographic analyses of the medium from such cultures grown in the presence or absence of cyclic AMP revealed that the only compound not common to both cultures was cyclic AMP itself. That the extra nitrogen supply was not obtained by deamination of cyclic AMP to cyclic IMP was also determined in these high glucose experiments, as growth ceased before either glucose or cyclic AMP were exhausted.

\section{DISCUSSION}

Beneckea natriegens grown on either succinate or glucose contained 5 to $8 \mathrm{nmol}$ ATP per mg dry bacterial wt during exponential growth, a range in keeping with those of a wide variety of other bacteria. The adenylate energy charge remained approximately constant at 0.9 , a figure in general agreement with those of 0.7 to 0.9 found in a wide range of actively growing bacteria, in which values have been estimated from experiments often involving delays of several seconds between sampling from the growing culture and quenching of 
metabolic activity (Franzen \& Binkley, I96I ; Harrison \& Maitra, I969; Setlow \& Kornberg, 1970; Chapman et al., 1971 ; Liao \& Atkinson, I971 ; Lowry et al., 1971 ; Miović \& Gibson, I97I, 1973; Decker \& Pfitzer, 1972; Bächi \& Ettlinger, 1973; Dietzler et al., I974a; Hanson \& Dworkin, 1974; Hutchison \& Hanson, 1974; Swedes et al., 1975; Winkler, 1976). There have been reports of lower energy charge values in growing bacteria but these have involved filtration or harvesting procedures, or unusual quenching methods (Fanica-Gaignier, Clement-Metral \& Kamen, 197I ; Schmidt \& Kamen, I97I ; Eigener, 1975).

When growing aerobically on glucose, Escherichia coli (strain ML308) excretes acetate into the medium (Holms \& Bennett, I97I); after glucose exhaustion there is a second respiratory phase when acetate is oxidized but no growth occurs. Holms et al. (I972) showed that during the acetate-oxidizing phase, the intracellular ATP pool is maintained at the level found during active growth and it is only after total oxidation of the acetate that respiratory activity and ATP content decrease. In contrast, Chapman et al. (I97r) found that depletion of glucose causes an immediate decrease in the total adenine nucleotide content of $E$. coli (strain B), presumably due largely to loss of ATP as the energy charge fell simultaneously (to about 0.6 ). The latter workers did not measure the content of acetate in the medium or look for a second respiratory phase, but the differences are difficult to reconcile unless they are due to the different strains of $E$. coli used.

It is interesting to compare changes in the adenine nucleotide pools of glucose-grown $E$. coli with those of $B$. natriegens since the latter also excretes organic acids (principally pyruvate) when grown on glucose (Eagon \& Cho, 1965; Figs 3 and 5) and these acids are also oxidized following glucose exhaustion. In B. natriegens, there is an immediate rise in the intracellular ATP and total adenine nucleotide contents after exhaustion of glucose together with maintenance of the energy charge at about 0.9 (Fig. 3). The increased adenine nucleotide content is maintained during the second respiratory phase but decreases to near the growth value following exhaustion of the volatile acids. Throughout the time after glucose exhaustion and during at least $4 \mathrm{~h}$ further starvation, the energy charge is still maintained at 0.8 to 0.9 . A transient increase in adenine nucleotide content is also observed following cessation of growth due to $\mathrm{pH}$ limitation. Thereafter bacterial lysis begins and both intracellular adenine nucleotide content and energy charge decrease dramatically. Similarly, a small transient increase in adenine nucleotide content is observed on exhaustion of succinate from carbon-limited cultures although no second respiratory phase occurs (Fig. I); however, the ATP pool is thereafter maintained near the growth value and the energy charge remains high during several hours of starvation.

These transient or maintained increases in adenine nucleotide levels, which occur once growth has ceased, could be due to the decreased demand for ATP and the simultaneous metabolism of endogenous and/or exogenous reserve products.

In all previous investigations, starvation resulted in a decrease in the total adenine nucleotide or ATP content of the bacteria and a lowering of the energy charge (Chapman et al., 1971; Bächi \& Ettlinger, 1973; Miović \& Gibson, 1973; Montague \& Dawes, 1974; Eigener, 1975; Gadkari \& Stolp, 1975). Surprisingly B. natriegens not only maintains the total adenine nucleotide pool at the growth value for several hours after substrate depletion, but the energy charge also remains relatively unaffected. We do not, as yet, understand the reasons for these unexpected phenomena. A minor, experimentally undetectable decrease in energy charge may cause a major shift in metabolic activity such that the growth-related processes of macromolecular synthesis, etc., are greatly reduced; the breakdown of endogenous reserve polymers, RNA or peptides may provide sufficient energy to maintain the energy charge at this level. Preliminary experiments suggest that little poly- $\beta$-hydroxybutyrate 
or glycogen storage occurs in carbon-limited succinate- or glucose-grown B. natriegens (unpublished observations) and the nature of such endogenous material remains obscure. In addition, $B$. natriegens may have an exceptionally low requirement for energy of maintenance and 'slip' (Stouthamer \& Bettenhaussen, 1973; Neijssel \& Tempest, 1976) and hence show only a very slow decrease in adenine nucleotide pool sizes or energy charge.

When growth of $B$. natriegens is inhibited by nitrogen limitation, the ATP content steadily increases until, or just after, the carbon source is exhausted (Figs 2 and 4). However, the energy charge remains relatively constant at about 0.9 . The increase in adenine nucleotide content, which must be due to de novo synthesis of AMP during the substrate-sufficient phase, is surprising as no exogenous nitrogen is available at this time. Possibly $B$. natriegens contains a reserve of adenosine or other precursor of AMP which is converted to the nucleotide when there is a very high prevailing energy charge. Alternatively, breakdown of RNA to release AMP could occur but if so, some regulatory factor other than energy charge would be required to control this process. In contrast, nitrogen limitation of E. coli ML308 growing on excess glycerol stabilizes the ATP pool at the level found in growing cells (Holms et al., 1972). Similarly, in glucose-grown $E$. coli $\mathrm{B}$, the total adenine nucleotide content and the energy charge following nitrogen limitation remain at the levels observed during growth (Chapman et al., 1971). However, Dietzler et al. (1974a) have shown that nitrogen limitation of glucose-grown E. coli strain KI 2 (W4597-K) causes the energy charge to increase from the rather low growth value of 0.74 to 0.87 , although there is no increase in the total adenine nucleotide content. During the non-growing, glucose-oxidizing phase, massive deposition of glycogen occurs which the authors claim is a consequence of the rise in energy charge (see Shen \& Atkinson, 1970).

During the non-growing, nitrogen-limited but glucose- or succinate-sufficient phase, $B$. natriegens also synthesizes much glycogen (unpublished observations). Glycogen formation, RNA breakdown, AMP synthesis and degradation, and other metabolic changes that occur in $B$. natriegens during this period are currently under investigation.

After exhaustion of succinate or glucose, the ATP content of nitrogen-limited B. natriegens decreased and thereafter attained a new level associated with endogenous metabolism (Figs 2 and 4). Despite these fluctuations, which are probably due to metabolic reorganization, the energy charge values were maintained at the levels characteristic of the nongrowing, substrate-sufficient phases. Such stabilization of energy charge, irrespective of the adenine nucleotide pool levels, has been evident throughout these studies and strongly supports the idea that enzymes involved in AMP breakdown are influenced by the adenylate energy charge (Chapman \& Atkinson, 1973; Schramm \& Leung, 1973; Schramm \& Lazorik, I975).

Since cyclic AMP influences many processes associated with bacterial bioenergetics (Hempfling, 1970; Hempfling \& Beeman, 197I; Patrick \& Dobrogosz, I973; Broman et al., 1974; Ezzell \& Dobrogosz, 1975; Hempfling \& Mainzer, 1975; Takahashi, 1975), we tested the effect of added cyclic AMP on glucose-grown carbon- and nitrogen-limited cultures of B. natriegens. In both cases, cyclic AMP had little or no effect on the energy charge or bacterial ATP contents during exponential growth (Fig. 5). However, significantly less acid was produced; cyclic AMP presumably induced synthesis of tricarboxylic acid cycle enzymes (Takahashi, 1975) allowing more complete oxidation of the products of glucose catabolism. Although the reduced acid production caused a marked decrease in the duration of the second respiratory phase in carbon-limited cultures, the non-growing, substratesufficient respiratory phase in nitrogen-limited cultures was not significantly altered; the reasons for this are obscure. Although the energy charge remained high and relatively 
stable both during and after the second respiratory phases, the intracellular ATP contents were considerably elevated in the presence of cyclic AMP. Interestingly on exhaustion of the acids in the glucose-limited culture (Fig. 5), the ATP content returned to a plateau level significantly higher than that observed during exponential growth.

As cyclic AMP can therefore influence the magnitude of the adenine nucleotide pools under certain circumstances, both adenylate energy charge and cyclic AMP may be intimately involved in the overall control of bacterial metabolism.

We are grateful to the Science Research Council for financial support.

\section{REFERENCES}

AtKinson, D. E. (1968). The energy charge of the adenylate pool as a regulatory parameter. Interaction with feedback modifiers. Biochemistry, New York 7, 4030-4034.

AtKinson, D. E. \& Walton, G. M. (I967). Adenosine triphosphate conservation in metabolic regulation. Rat liver citrate cleavage enzyme. Journal of Biological Chemistry 242, 3239-324I.

BÄCHI, B. \& ETTLINGER, L. (1973). Influence of glucose on adenine nucleotide levels and energy charge in Acetobacter aceti. Archiv für Mikrobiologie 93, 155-164.

BAgNARA, A. A. \& FinCH, L. R. (1973). Relationships between intracellular contents of nucleotides and 5-phosphoribosyl 1-pyrophosphate in Escherichia coli. European Journal of Biochemistry 36, 422-427.

BaLL, W. J., JR \& AtKInson, D. E. (1975). Adenylate energy charge in Saccharomyces cerevisiae during starvation. Journal of Bacteriology I21, 975-982.

Baumann, P., BaumanN, L. \& Mandel, M. (1971). Taxonomy of marine bacteria: the genus Beneckea. Journal of Bacteriology ro7, 268-294.

Broman, R. L., Dobrogosz, W. J. \& WHITE, D. C. (1974). Stimulation of cytochrome synthesis in Escherichia coli by cyclic AMP. Archives of Biochemistry and Biophysics 162, 595-601.

Chapman, A. G. \& AtKinson, D. E. (1973). Stabilization of adenylate energy charge by the adenylate deaminase reaction. Journal of Biological Chemistry 248, 8309-8312.

Chapman, A. G., Fall, L. \& AtKinson, D. E. (I97I). Adenylate energy charge in Escherichia coli during growth and starvation. Journal of Bacteriology ro8, 1072-1086.

Chulavatnatol, M. \& AtKinson, D. E. (1973a). Phosphoenolpyruvate synthetase from Escherichia coli. Effects of adenylate energy charge and modifier concentrations. Journal of Biological Chemistry 248, 27I $2-2715$.

Chul avatnatol, M. \& AtKinson, D. E. (1973b). Kinetic competition in vitro between phosphoenolpyruvate synthetase and the pyruvate dehydrogenase complex from Escherichia coli. Journal of Biological Chemistry 248, 2716-2721.

DeCKer, K. \& PFiTZer, S. (1972). Determination of steady-state concentrations of adenine nucleotides in growing C. kluyveri cells by biosynthetic labeling. Analytical Biochemistry 5o, 529-539.

DieTzLER, D. N., LAis, C. J. \& LeCKIE, M. P. (I974a). Simultaneous increases of the adenylate energy charge and the rate of glycogen synthesis in nitrogen-starved Escherichia coli $\mathbf{W} 4597(\mathrm{~K})$. Archives of Biochemistry and Biophysics 160, 14-25.

Dietzler D. N., Lais, C. J., Magnani, J. L. \& Leckie, M. P. (1974 b). Maintenance of the energy charge in the presence of large decreases in the total adenylate pool of Escherichia coli and concurrent changes in glucose-6-P, fructose- $\mathrm{P}_{2}$ and glycogen synthesis. Biochemical and Biophysical Research Communications 6o, $875-88 \mathrm{I}$.

EAGon, R. G. (1962). Pseudomonas natriegens, a marine bacterium with a generation time of less than Io minutes. Journal of Bacteriology 83, 736-737.

EAGON, R. G. \& CHO, H. W. (1965). Major products of glucose dissimilation by Pseudomonas natriegens. Journal of Bacteriology 89, I 209-I 21 I.

EIGENER, U. (1975). Adenine nucleotide pool variations in intact Nitrobacter winogradskyi cells. Archives of Microbiology 102, 233-240.

EIGENER, U. \& Bock, E. (1975). Study of the regulation of oxidation and $\mathrm{CO}_{2}$ assimilation in intact Nitrobacter winogradskyi cells. Archives of Microbiology 102, 24 I-246.

Ezzell, J. W. \& Dobrogosz, W. J. (1975). Altered hexose transport and salt sensitivity in a cyclic adenosine 3', 5'-monophosphate-deficient Escherichia coli. Journal of Bacteriology 124, 81 5-824.

Fanica-Gaignier, M., Clement-Metral, J. \& Kamen, M. D. (I97I). Adenine nucleotide levels and photopigment synthesis in a growing photosynthetic bacterium. Biochimica et biophysica acta 226, I35-143.

Franzen, J. S. \& BinkLey, S. B. (I96I). Comparison of acid-soluble nucleotides in Escherichia coli at different growth rates. Journal of Biological Chemistry 236, 5I5-519. 
GADKARI, D. \& STOLP, H. (1975). Energy metabolism of Bdellovibrio bacteriovorus. I. Energy production, ATP pool, energy charge. Archives of Microbiology 102, 179-185.

HANSON, C. W. \& DWORKIN, M. (I974). Intracellular and extracellular nucleotides and related compounds during the development of Myxococcus xanthus. Journal of Bacteriology II8, 486-496.

Harrison, D. E. F. \& MaITRA, P. K. (1969). Control of respiration and metabolism in growing Klebsiella aerogenes. The role of adenine nucleotides. Biochemical Journal II2, 647-656.

HeMPfLING, W. P. (1970). Repression of oxidative phosphorylation in Escherichia coli в by growth in glucose and other carbohydrates. Biochemical and Biophysical Research Communications 4I, 9-15.

Hempfling, W. P. \& BeEMAN, D. K. (I97I). Release of glucose repression of oxidative phosphorylation in Escherichia coli в by cyclic adenosine $3^{\prime}, 5^{\prime}$-monophosphate. Biochemical and Biophysical Research Communications 45, 924-930.

Hempfling, W. P. \& MAinZer, S. E. (1975). Effects of varying the carbon source limiting growth on yield and maintenance characteristics of Escherichia coli in continuous culture. Journal of Bacteriology 123, 1076-1087.

Hobson, P. N. \& SUmmers, R. (1972). ATP pool and growth yield in Selenomonas ruminantium. Journal of General Microbiology 7o, 35I-360.

Holms, W. H. \& BENNETT, P. M. (1971). Regulation of isocitrate dehydrogenase activity in Escherichia coli on adaptation to acetate. Journal of General Microbiology 65, 57-68.

Holms, W. H., HamiLton, I. D. \& RoBer TSON, A. G. (1972). The rate of turnover of the adenosine triphosphate pool of Escherichia coli growing aerobically in simple defined media. Archiv für Mikrobiologie 83, 95-109.

Hutchison, K. W. \& Hanson, R. S. (1974). Adenine nucleotide changes associated with the initiation of sporulation in Bacillus subtilis. Journal of Bacteriology 119, 70-75.

Klungsøyr, L., Hagemen, J. H., Fall, L. \& Atkinson, D. E. (I968). Interaction between energy charge and product feedback in the regulation of biosynthetic enzymes. Aspartokinase, phosphoribosyladenosine triphosphate synthetase and phosphoribosyl pyrophosphate synthetase. Biochemistry, New York 7, 4035-4040.

LIAO, C-L. \& ATKInSON, D. E. (1971). Regulation at the phosphoenolpyruvate branchpoint in Azotobacter vinelandii: pyruvate kinase. Journal of Bacteriology 106, 37-44.

LOWRY, O. H., CARTER, J., WARD, J. B. \& GLASER, L. (I971). The effect of carbon and nitrogen sources on the level of metabolic intermediates in Escherichia coli. Journal of Biological Chemistry 246, 65I I-652I.

LUNDIN, A. \& THORE, A. (1975). Comparison of methods for extraction of bacterial adenine nucleotides determined by firefly assay. Applied Microbiology 30, 713-721.

Miller, A. L. \& AtKinson, D. E. (1972). Response of yeast pyruvate carboxylase to the adenylate energy charge and other regulatory parameters. Archives of Biochemistry and Biophysics 152, 53I-538.

Mıović, M. L. \& GiBson, J. (1971). Nucleotide pools in growing Chromatium strain D. Journal of Bacteriology 108, 954-956.

Miović, M. L. \& Gibson, J. (1973). Nucleotide pools and adenylate energy charge in balanced and unbalanced growth of Chromatium. Journal of Bacteriology 114, 86-95.

Montague, M. D. \& Dawes, E. A. (1974). The survival of Peptococcus prévotii in relation to the adenylate energy charge. Journal of General Microbiology 80, $29 \mathrm{I}-299$.

Neidhardt, F. C. \& Fraenkel, D. G. (I96I). Metabolic regulation of RNA synthesis in bacteria. Cold Spring Harbor Symposia on Quantitative Biology 26, 63-74.

NeiJssel, O. M. \& TeMPEST, D. W. (1976). Bioenergetic aspects of aerobic growth of Klebsiella aerogenes NCTC 418 in carbon-limited and carbon-sufficient chemostat culture. Archives of Microbiology 107, $215-221$.

Patrick, J. M. \& Dobrogosz, W. J. (1973). The effect of cyclic AMP on anaerobic growth of Escherichia coli. Biochemical and Biophysical Research Communications 54, 555-561.

Purich, D. L. \& Fromm, H. J. (I972). Studies on factors influencing enzyme responses to adenylate energy charge. Journal of Biological Chemistry 247, 249-255.

Purich, D. L. \& Fromm, H. J. (I973). Additional factors influencing enzyme responses to the adenylate energy charge. Journal of Biological Chemistry 248, 46I-466.

Rickenkerg, H. V. (1974). Cyclic AMP in prokaryotes. Annual Review of Microbiology 28, 353-369.

SchmidT, G. L. \& KAMEN, M. D. (I97I). Control of chlorophyll synthesis in Chromatium vinosum. Archiv für Mikrobiologie 76, 5I-64.

Schramm, V. L. \& LAZORIK, F. C. (1975). The pathway of adenylate catabolism in Azotobacter vinelandii. Evidence for adenosine monophosphate nucleosidase as the regulatory enzyme. Journal of Biological Chemistry 250, $180 \mathrm{I}-1808$.

Schramm, V. L. \& LeUng, H. (1973). Regulation of adenosine monophosphate levels as a function of adenosine triphosphate and inorganic phosphate. A proposed metabolic role for adenosine monophosphate nucleosidase from Azotobacter vinelandii. Journal of Biological Chemistry 248, 831 3-8315.

Setlow, P. \& KornBerg, A. (1970). Biochemical studies of bacterial sporulation and germination. XXII. Energy metabolism in early stages of germination of Bacillus megaterium spores. Journal of Biological Chemistry 245, 3637-3644. 
SHEN, L. C. \& AtKinson, D. E. (1970). Regulation of adenosine dephosphate glucose synthase from Escherichia coli. Interactions of adenylate energy charge and modifier concentrations. Journal of Biological Chemistry 245, 3996-4000.

Shen, L. C., Fall, L., Walton, G. M. \& Atkinson, D. E. (I968). Interaction between energy charge and metabolite modulation in the regulation of enzymes of amphibolic sequences. Phosphofructokinase and pyruvate dehydrogenase. Biochemistry, New York 7, 404I-4045.

Slayman, C. L. (1973). Adenine nucleotide levels in Neurospora, as influenced by conditions of growth and by metabolic inhibitors. Journal of Bacteriology II4, 752-766.

SMith, R. C. \& MAALøE, O. (1964). Effect of growth rate on the acid-soluble nucleotide composition of Salmonella typhimurium. Biochimica et biophysica acta 86, 229-234.

Stouthamer, A. H. \& BetTenhaussen, C. (1973). Utilization of energy for growth and maintenance in continuous and batch cultures of micro-organisms. A re-evaluation of the method for the determination of ATP production by measuring molar growth yields. Biochimica et biophysica acta 30r, 53-70.

Swedes, J. S., Sedo, R. J. \& ATKINSON, D. E. (I975). Relation of growth and protein synthesis to the adenylate energy charge in an adenine-requiring mutant of Escherichia coli. Journal of Biological Chemistry 250, 6930-6938.

TAKAHASHI, Y. (1975). Effect of glucose and cyclic adenosine $3^{\prime}, 5^{\prime}$-monophosphate on the synthesis of succinate dehydrogenase and isocitrate lyase in Escherichia coli. Journal of Biochemistry 78, I097-1 100.

Thompson, F. M. \& AtKInson, D. E. (197I). Response of nucleoside diphosphate kinase to the adenylate energy charge. Biochemical and Biophysical Research Communications 45, 1581-1585.

WinkLeR, H. H. (1976). Rickettsial permeability. An ADP-ATP transport system. Journal of Biological Chemistry 25I, 389-396. 